\title{
PENGARUH PERSEPSI PESERTA DIDIK MENGENAI KEMAMPUAN KOMUNIKASI GURU TERHADAP HASIL BELAJAR EKONOMI KELAS XI MA AN-NIZHAMIYYAH CILEUNGSI, BOGOR
}

\author{
${ }^{1}$ Nyai Suhartini dan ${ }^{2}$ Elin Karlina \\ ${ }^{1}$ Mahasiswa Program Studi Pendidikan Ekonomi Universitas Indraprasta PGRI \\ ${ }^{2}$ Dosen Program Studi Pendidikan Ekonomi Universitas Indraprasta PGRI \\ e-mail : ai_najla@yahoo.co.id
}

\begin{abstract}
Abstrak
Penelitian ini bertujuan untuk mengetahui pengaruh persepsi peserta didik mengenai kemampuan komunikasi guru terhadap hasil belajar ekonomi di kelas XI MA AN-NIZHAMIYYAH Cileungsi, Bogor. Metode penelitian yang digunakan adalah peneltian kuantitatif dengan pendekatan survey dan tes hasil belajar peserta didik. Jumlah sampelnya adalah 32 peserta didik. Adapun simpulan penelitian menunjukan bahwa terdapat pengaruh persepsi peserta didik mengenai kemampuan komunikasi guru terhadap hasil belajar ekonomi, dengan didukung hasil perhitungan regresi didapat adalah $\hat{y}=55,518+0,317 x$ hal ini menunjukkan bahwa nilai regresi tersebut bernilai positif dan searah, perhitungan korelasi didapat data $\mathrm{r}_{\text {hitung }}$ sebesar 0,581 hal ini menunjukkan bahwa terdapat kategori hubungan yang sedang, hasil koefisien determinasi didapat jumlah kontribusi persepsi peserta didik mengenai kemampuan komunikasi guru terhadap hasil belajar sebesar $33,75 \%$, serta berdasarkan hasil uji hipotesis didapat nilai $t_{\text {hitung }}>t_{\text {tabel }}$ $(3,91>2,04)$ yang menyatakan bahwa terdapat pengaruh persepsi peserta didik mengenai kemampuan komunikasi guru terhadap hasil belajar ekonomi.
\end{abstract}

Kata kunci : Persepsi Kemampuan Komunikasi, Hasil Belajar

\section{PENDAHULUAN}

Pendidikan kita dewasa ini menghadapi berbagai tantangan dan persoalan, diantaranya yaitu bertambahnya jumlah penduduk yang sangat cepat dan sekaligus bertambahnya keinginan masyarakat untuk mendapatkan pendidikan yang secara kumulatif dan menuntut tersedianya sarana pendidikan yang memadai. Berkembangnya ilmu pengetahuan yang modern menghendaki dasar-dasar pendidikan yang kokoh dan penguasaan kemampuan terus menerus, dengan demikian menuntut pendidikan yang lebih lama sesuai dengan konsep pendidikan seumur hidup (long life education).

Dengan adanya tantangan dan persoalan dalam bidang pendidikan, pembaharuan merupakan keharusan yang mutlak diperlukan untuk memenuhi solusi dan mencerahkan dengan pemikiran baru yang mendalam dan progresif, serta upaya dasar untuk memperbaiki dan meningkatkan aspek pendidikan agar lebih efisien, efektif, dan produktif. Kegiatan pengajaran di sekolah merupakan bagian dari kegiatan pendidikan pada umumnya secara otomatis meningkatkan hasil belajar peserta didik ke arah yang lebih baik. Bila kita amati keberhasilan dalam proses belajar mengajar dapat dilihat dari 
hasil belajar peserta didik serta kemampuan komunikasi guru, karena komunikasi merupakan suatu aktifitas dasar manusia, dengan adanya komunikasi maka semua aktifitas akan berjalan dengan sangat baik.

Komunikasi juga harus dilakukan pada saat guru melakukan interaksi belajar mengajar, sehingga seorang guru harus memiliki kemampuan dalam berkomunikasi agar apa yang akan disampaikan dapat dipahami dan terserap dengan sempurna oleh peserta didiknya. Pelaksanaan komunikasi dalam kegiatan belajar mengajar dipengaruhi oleh beberapa faktor, misalnya kondisi guru sebagai penyampai pesan, kondisi peserta didik sebagai sasaran komunikasi, media/saluran yang digunakan dalam kegiatan belajar mengajar, serta situasi dan lingkungan kelas. Guru sebagai kunci dalam kegiatan belajar mengajar di kelas memiliki peranan penting untuk memimpin dan mengarahkan kegiatan belajar pada peserta didiknya.

Meski demikian, seorang guru juga memiliki kemungkinan untuk melakukan kesalahan yang dapat menghambat kelancaran komunikasi. Sehingga pada akhirnya turut mempengaruhi keefektifan dalam memahamkan materi kepada peserta didik. Beberapa kemungkinan kesalahan yang bisa terjadi pada pihak sumber disebabkan oleh beberapa faktor, antara lain dalam penggunaan bahasa, perbedaan pengalaman, keahlian, kondisi mental, sikap, dan penampilan fisik.

Kemampuan guru untuk menyampaikan materi di kelas harus dioptimalkan agar peserta didik mampu mengerti dan memahami materi yang diajarkan. Kegiatan belajar mengajar di kelas seharusnya dimanfaatkan para pendidik untuk meningkatkan potensi peserta didik maupun kemampuan untuk berkomunikasi. Namun biasanya guru lebih banyak menghabiskan waktunya untuk berbicara di depan kelas dan kurang memberi kesempatan kepada peserta didik untuk mengungkapkan pendapatnya. Selain itu, gaya berbicara serta kejelasan intonasi suara juga memberikan andil yang cukup besar untuk mendukung pelaksanaan komunikasi yang efektif.

Kondisi dari peserta didik juga mempengaruhi kelancaran aliran komunikasi dalam kegiatan belajar di kelas. Peserta didik memiliki karakteristik yang berbeda satu sama lain. Setiap peserta didik memiliki kemampuan, minat, dan motivasi yang berbeda. Kondisi peserta didik akan mempengaruhi kemampuannya dalam menangkap informasi yang disampaikan guru. 
Kondisi fisik maupun mental peserta didik serta kemampuan setiap peserta didik yang berbeda akan memberi dampak cukup besar dalam keberhasilan pembelajaran. Fisik yang lelah ataupun beban pikiran akan berpengaruh dalam proses belajar peserta didik. Seorang guru hendaknya mampu mengenali dan memahami berbagai karakteristik tersebut. Namun guru cenderung kurang memperhatikan keberagaman tersebut, sehingga peserta didik merasa kurang diperhatikan dan malas mengikuti pelajaran.

Cara pandang peserta didik terhadap suatu pelajaran maupun pengajar juga memberikan dampak yang cukup besar dalam kegiatan belajar di kelas. Adakalanya, peserta didik memandang remeh suatu pelajaran, atau kurang menyukai guru pengampu pelajaran sehingga timbul rasa malas untuk mengikuti pelajaran tersebut.

\section{TINJAUAN PUSTAKA}

\section{Hasil Belajar Ekonomi}

Belajar akan membawa perubahan pada individu setelah mengalami aktivitas belajar. Perubahan tersebut dapat dilihat dari hasil belajar yang meliputi perubahan pengetahuan, sikap, kecakapan, dan lain-lain. Seseorang yang telah mengalami proses belajar tidak sama keadaannya bila dibandingkan dengan keadaan pada saat sebelum belajar, individu akan lebih sanggup menghadapi kesulitan, memecahkan masalah atau menyesuaikan diri dengan situasi dan kondisi yang dihadapinya.

Bloom (Slameto, 2010: 123), menyatakan bahwa "hasil belajar mencakup ranah kognitif, afektif dan psikomotorik”. Ketiga aspek tersebut menjadi objek penilaian hasil belajar, ranah kognitif paling banyak dinilai oleh para guru di sekolah karena berkaitan dengan kemampuan para peserta didik dalam menguasai isi bahan pengajaran.

Surakhmad (2012: 25) menyatakan bahwa "hasil belajar adalah ulangan, ujian, atau tes". Maksud ulangan tersebut adalah untuk memperoleh suatu indeks dalam menentukan keberhasilan peserta didik. Sedangkan menurut Hidayat (2013: 82), "hasil belajar adalah kemampuan yang diperoleh anak setelah melalui kegiatan belajar”.

Kemampuan yang dimiliki peserta didik dapat dilihat dari hasil belajarnya setelah ia menerima pengalaman belajar. Peserta didik yang belajar akan memperoleh hasil dari apa yang telah ia pelajari selama proses belajar, karena hasil belajar merupakan suatu perubahan yang terjadi pada peserta didik yang belajar, bukan hanya perubahan mengenai pengetahuan, tetapi juga untuk membentuk kecakapan, kebiasaan, pengertian, 
penguasaan, dan penghargaan dalam diri seseorang yang belajar. Hasil penilaian pada dasarnya adalah hasil belajar yang diukur, dan merupakan umpan balik untuk mengetahui sampai dimana proses belajar mengajar yang telah dilaksanakan.

Kegiatan belajar mengajar tidak terlepas dari hasil pembelajaran. Sering kali kita lihat dalam realita di lapangan bahwa ada peserta didik yang memiliki hasil belajar yang memuaskan, cukup dan bahkan ada juga yang kurang memuaskan. Hal ini tidak terlepas dari adanya beberapa faktor yang menyebabkan perbedaan hasil belajar peseta didik.

Menurut Suryabrata (Hidayat, 2013: 85) menyatakan "faktor faktor yang dapat mempengaruhi hasil belajar dapat digolongkan pada dua bagian yaitu faktor internal (dari dalam diri peserta didik) dan faktor eksternal (dari luar peserta didik)”.

\section{Faktor Internal}

a) Aspek Fisiologis

Secara umum kondisi fisiologis seperti, kesehatan jasmani dan rohani yang memiliki pengaruh terhadap kemampuan belajar karena apabila kesehatan kurang baik maka dapat mengganggu atau mengurangi semangat belajar.

b) Aspek Psikologis

Setiap individu dalam hal ini peserta didik pada dasarnya memiliki kondisi psikologis yang berbeda-beda, tentunya hal ini turut mempengaruhi hasil belajarnya. Beberapa faktor psikologis meliputi intelegensi (IQ), perhatian, minat, bakat, motif, motivasi, dan daya nalar peserta didik.

2. Faktor Eksternal

a) Faktor Lingkungan

Faktor lingkungan dapat mempengaruhi hasil belajar. Faktor lingkungan ini meliputi lingkungan fisik dan lingkungan sosial, dalam lingkungan fisik terutama pada kondisi alam yang sangat mempengaruhi hasil belajar seperti suhu, kelembaban, dan lain-lain. Belajar pada tengah hari diruangan yang kurang akan sirkulasi udara akan sangat berpengaruh dan akan sangat berbeda pada pembelajaran di pagi hari yang kondisinya masih segar.

b) Faktor Instrumental

Faktor instrumental adalah faktor yang keberadaan dan penggunaanya dirancang sesuai dengan hasil belajar yang diharapkan. Faktor ini diharapkan 
dapat berfungsi sebagai sarana untuk tercapainya tujuan-tujuan belajar yang direncanakan. Faktor instrumental ini berupa sarana dan prasarana belajar.

Mata Pelajaran Ekonomi merupakan pelajaran yang diajarkan pada peserta didik kelas XI. Adapun salah satu kegiatan pembelajaran dari materi pelajaran yang dilaksanakan di kelas adalah menjelaskan tentang tata cara penyusunan laporan keuangan perusahan jasa, yang dimulai dari :

1) Mendeskripsikan akuntansi sebagai sistem informasi

2) Menafsirkan persamaan akuntansi

3) Mencatat transaksi berdasarkan mekanisme debit/kredit

4) Mencatat transaksi/dokumen ke dalam jurnal umum

5) Melakukan posting dari jurnal ke buku besar

\section{Persepsi Peserta Didik Mengenai Kemampuan Komunikasi Guru Persepsi peserta didik}

Komunikasi yang terjadi antar individu akan menimbulkan berbagai persepsi antar pelaku komunikasi. Menurut Desiderato (Rakhmat, 2007: 51) menyatakan bahwa "persepsi adalah pengalaman tentang objek, peristiwa, atau hubungan hubungan yang diperoleh dengan menyimpulkan informasi dan menafsirkan pesan. Persepsi ialah memberikan makna pada stimuli inderawi (sensory stimuli)".

Slameto (2010: 102) menyatakan bahwa "Persepsi adalah proses yang menyangkut masuknya pesan atau informasi kedalam otak manusia. Melalui persepsi manusia terus menerus mengadakan hubungan dengan lingkungannya. Hubungan ini dilakukan lewat inderanya, yaitu indera penglihat, pendengar, peraba, perasa dan pencium".

Persepsi dapat diartikan sebagai cara pandang ataupun pemaknaan dari seorang individu terhadap berbagai hal yang ada di sekitarnya. Cara pandang setiap individu terhadap suatu hal akan berbeda meski objek yang dihadapi sama. Dalam komunikasi, persepsi dari pelaku komunikasi akan memberikan pengaruh yang cukup besar untuk menentukan keberhasilan komunikasi. Dalam kegiatan belajar, semua informasi yang disampaikan guru akan dipersepsi oleh peserta didik sesuai pengalaman yang dimiliki sebelumnya. 
Kemampuan setiap individu untuk mempersepsi objek yang ada dihadapannya berbeda-beda. Hal tersebut dipengaruhi oleh beberapa faktor, seperti yang disebutkan oleh David Krech dan Richard S. Crutchfield (Rakhmat, 2007: 51-62), antara lain:

1. Perhatian

Perhatian terjadi bila seorang individu mengkonsentrasikan diri pada salah satu alat inderanya, dan mengesampingkan masukan-masukan melalui alat indera yang lain. Faktor penarik perhatian dapat dibedakan menjadi dua, yaitu:

a) Faktor eksternal penarik perhatian antara lain gerakan manusia yang secara visual tertarik pada objek-objek yang bergerak, intensitas stimuli manusia yang akan memperhatikan stimuli yang lebih menonjol dari stimuli yang lain, kebaruan (novelty) dan petualangan.

b) Faktor internal penarik perhatian antara lain faktor-faktor biologis dan sosiopsikologis (motif sosiogenis, sikap, kebiasaan dan kemauan).

2. Faktor personal

Merupakan faktor fungsional yang berasal dari kebutuhan, pengalaman masa lalu dan berbagai hal lainnya, seperti: karakteristik orang yang memberikan respon pada stimuli itu, suasana mental komunikan dan latar belakang budaya.

3. Faktor struktural

Dalam hal ini persepsi dipengaruhi kedekatan objek pada struktur (kelompok) tertentu. Perbedaan pengelompokan dipengaruhi oleh perbedaan pendidikan dan kebudayaan.

Kemampuan setiap peserta didik dalam mempersepsi materi yang diajarkan guru tidaklah sama meskipun dalam satu kelas yang sama. Hal ini ditentukan oleh peserta didik sendiri dalam aktivitas komunikasi baik sebagai komunikator maupun komunikan. Selain itu, pengetahuan dan pengalaman yang dimiliki peserta didik akan memperkaya benaknya dengan perbendaharaan untuk memperkuat daya persepsinya.

Perbedaan persepsi setiap peserta didik perlu mendapat perhatian dari guru dalam pelaksanaan pembelajaran. Setidaknya guru dapat memperkecil perbedaan-perbedaan tersebut sehingga mampu mengupayakan agar sasaran bisa memiliki persepsi yang sama terhadap setiap informasi yang disampaikan. Dengan demikian, komunikasi yang terjadi dalam kegiatan belajar mengajar dapat berjalan dengan efektif. Seorang guru dapat menghindari adanya salah persepsi (atau perbedaan persepsi) dari peserta didik terhadap 
informasi yang disampaikan dengan cara antara lain: menggunakan media pembelajaran yang mendekati bentuk dan fungsi benda aslinya, menjelaskan secara sistematis dan mengambil contoh-contoh nyata yang ada dalam kehidupan sehari hari.

\section{Kemampuan Komunikasi}

Cangara (2014: 35) menyatakan bahwa "Komunikasi atau communication berasal dari bahasa Latin yaitu commnicatio, dan bersumber dari kata communis yang berarti sama, sama disini maksudnya adalah sama makna. Komunikasi ini bisa terjadi apabila antara dua orang atau lebih melakukan komunikasi sama sama memahami makna yang akan disampaikan".

Rogers (Cangara, 2014: 35) seorang pakar Sosiologi Pedesaan Amerika menyatakan bahwa "komunikasi adalah proses dimana suatu ide dialihkan dari sumber kepada satu penerima atau lebih dengan maksud untuk mengubah tingkah laku mereka".

Seller (Sunarto, 2007: 56) ia memberikan definisi yang lebih universal, yaitu "komunikasi adalah proses dengan mana simbol verbal dan nonverbal dikirimkan, diterima, dan diberi arti”. Proses komunikasi menurut Seller ini sangat sederhana, yaitu mengirim dan menerima pesan tetapi sesungguhnya komunikasi adalah sebuah fenomena yang kompleks yang sulit dipahami tanpa mengetahui prinsip dan komponen yang penting dari komunikasi tersebut.

Komunikasi terjadi jika kedua belah pihak sama-sama dapat mengolah dengan baik simbol yang disampaikan. Simbol itu dapat disebut pesan, dimana proses penyampaian melalui media dan terjadi perubahan atau respon terhadap pesan yang disampaikan. Bentuk komunikasi menurut Djamrahari (Syah ,2010: 233) adalah:

1. Bentuk proyek adalah cara penyajian pelajaran yang menitik tolak dari suatu masalah, kemudian dibahas dari berbagai segi yang berhubungan sehingga pemecahannya secara menyeluruh bermakna. Bentuk proyek suatu cara mengajar yang memberikan kesempatan kepada peserta didik untuk menggunakan unit kehidupan sehari hari sebagai bahan pelajarannya dan bertujuan agar peserta didik tertarik untuk belajar.

2. Bentuk eksperimen adalah bentuk pemberian kesempatan kepada peserta didik perorangan atau kelompok, untuk dilatih melakukan suatu proses atau percobaan. Bentuk ini mengajarkan kepada peserta didik diharapkan tidak begitu menelan sejumlah fakta yang ditemukan dalam percobaan yang dilakukan, sekaligus dapat 
dikembangkan berbagai keterampilan baik berupa menemukan fakta, mengumpulkan data, mengendalikan verbal dan memcahkan masalah yang dihadapinya secara nyata.

3. Bentuk pemberian tugas dan resitasi dengan arti guru menyuruh peserta didik dengan membaca, tetapi dengan menambahkan tugas tugas seperti mencari dan membaca buku buku lain sebagai bahan perbandingan. Resitasi adalah suatu persoalan yang dihadapi dengan masalah pelaporan peserta didik setelah mereka selesai mengerjakan suatu tugas.

4. Bentuk bermain peran ialah suatu cara penguasaan bahan pelajaran melalui pengembangan dan penghayatan peserta didik. Pengembangan imajinasi dan penghayatan yang dilakukan oleh peserta didik dengan memerankannya sebagai tokoh hidup atau benda mati. Dengan kegiatan ini akan membuat peserta didik lebih meresapi persoalan.

Dari bentuk-bentuk komunikasi di atas, dapat disimpulkan bahwa bentuk-bentuk komunikasi memiliki pelajaran agar peserta didik dapat mengembangkan imajinasi sehingga peserta didik mampu beradaptasi dengan guru.

Jika proses komunikasi dilukiskan dalam gambar, maka proses komunikasi tersebut dapat dilihat sebagai berikut

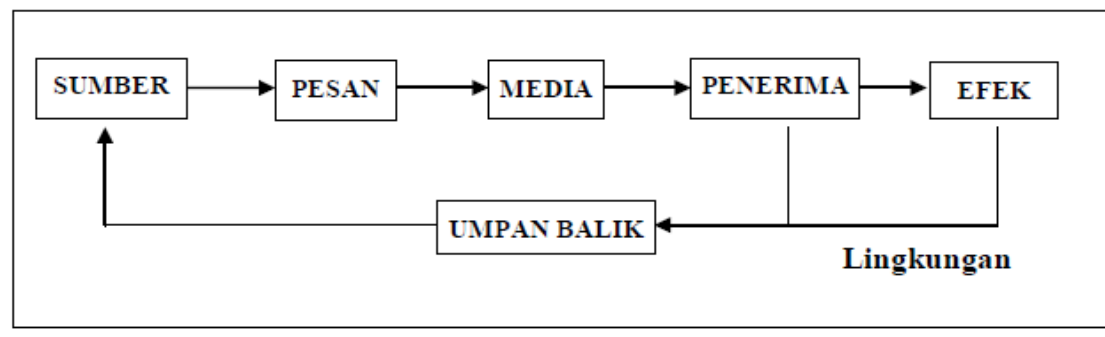

Gambar 1. Unsur-unsur dalam Komunikasi

Sumber: Cangara (2014:36)

Proses komunikasi pada hakikatnya adalah proses penyampaian pikiran atau perasaan oleh seseorang (komunikator) kepada orang lain (komunikan). Pikiran bisa berupa gagasan, informasi, opini, dan hal lain yang muncul dibenaknya.

Dalam dunia pendidikan guru dituntut untuk mampu berkomunikasi yang baik. Menurut Sudjana (2010: 200) "ada 3 pola komunikasi dalam dunia pendidikan yaitu 
komunikasi sebagai aksi (komunikasi satu arah), komunikasi sebagai interaksi (komunikasi dua arah) dan komunikasi sebagai transaksi”.

1. Komunikasi sebagai aksi (komunikasi satu arah)

Dalam komunikasi ini guru berperan sebagai pemberi aksi, peserta didik adalah pasif. Komunikasi ini biasanya yang dipergunakan adalah ceramah sehingga komunikasi satu arah ini kurang menghidupkan kegiatan peserta didik, karena peserta didik hanya mendengarkan guru dan menyampaikan materi pembelajaran.

2. Komunikasi sebagai interaksi (komunikasi dua arah)

Dalam komunikasi interaksi guru dan peserta didik memiliki peran yang sama yaitu sama sama sebagai pemberi aksi dan penerima aksi. Komunikasi interaksi ini akan terjalin komunikasi yang baik antara guru dengan peserta didiknya, namun dalam komunikasi ini akan membatasi antara komunikasi peserta didik dengan peserta didik lainnya.

3. Komunikasi sebagai transaksi

Dalam proses komunikasi sebagai transaksi tidak hanya melibatkan komunikasi yang dinamis antara guru dengan peserta didiknya namun juga peserta didik dengan peserta didik lainnya. Dalam pola komunikasi ini peserta didik dituntut untuk bisa aktif ketika sedang melakukan komunikasi, komunikasi yang biasa digunakan dalam pola ini adalah diskusi didalam kelas.

Mengelola kelas dan memecahkan konflik yang terjadi ketika di dalam kelas merupakan tugas dari seorang guru yang dituntut untuk menciptakan suasana yang kondusif dalam proses belajar mengajar. Untuk menciptakan suasana belajar yang kondusif tersebut guru harus memiliki kemampuan komunikasi yang baik dan harus memiliki strategi berkomunikasi ketika berada didalam kelas.

Menurut Santrock (Kennedy dan Soemanegara, 2009: 24) menyatakan bahwa "terdapat tiga aspek utama dari komunikasi pembelajaran, yaitu keterampilan berbicara, komunikasi verbal dan mendengarkan".

Kemampuan berbicara dimaksudkan agar apa yang akan disampaikan oleh guru dapat dipahami dan dimengerti oleh peserta didiknya. Strategi yang dapat dilakukan oleh guru untuk keterampilan berbicara adalah menggunakan kata-kata yang tepat ketika berkomunikasi dengan peserta didiknya dan menggunaan kosa kata sesuai dengan perkembangan peserta didiknya. 
Dalam komunikasi verbal yang harus diperhatikan oleh seorang guru adalah gaya penyampaian pesan. Ada dua penyampaian pesan dalam komunikasi verbal, yaitu komunikasi gaya "kamu” dan komunikasi gaya "saya". Gaya komunikasi kamu biasanya kurang disenangi oleh peserta didik karena terkesan menghakimi orang lain dan peserta didik berada dalam posisi defensif contohnya adalah "apa yang kamu sampaikan itu tidak tepat". Sedangkan gaya komunikasi saya bersifat merefleksikan perasaan, contohnya "saya lebih suka kamu mengemukakan pendapatmu".

Guru dan peserta didik harus memiliki keterampilan mendengar yang baik, karena seorang pendengar yang baik akan mendapatkan daya tarik bagi orang lain untuk berkomunikasi. Pendengar yang baik akan mendengar secara aktif berarti memperhatikan penuh pada si pembicara, memfokuskan diri pada isi intelektual dan emosional dari pesan.

Ditinjau dari prosesnya, pendidikan adalah komunikasi dalam arti kata bahwa dalam proses tersebut terlibat dua komponen yang terdiri atas manusia, yakni pengajar sebagai komunikator dan peserta didik sebagai komunikan. Proses komunikasi antara guru dan peserta didiknya haruslah sesuai dengan kualitas guru terhadap peserta didiknya.

Perbedaan antara komunikasi dengan pendidikan adalah terletak pada efek atau tujuan yang diharapkan. Dilihat dari efeknya komunikasi memiliki sifat yang umum sedangkan pendidikan memiliki sifat yang khusus. Tujuan pendidikan itu akan tercapai jika proses belajarnya komunikatif.

Pada umumnya pendidikan berlangsung secara terencana didalam kelas secara tatap muka (face to face). Karena kelompoknya relatif kecil, meskipun komunikasi antara guru dengan peserta didik dalam ruang kelas itu termasuk komunikasi kelompok. Tapi, sewaktu waktu bisa berubah menjadi komunikasi antar personal.

Komunikasi yang terjadi dapat bersifat dua arah apabila komunikan atau peserta didik memberi respon terhadap yang disampaikan oleh komunikator atau guru. Namun bisa juga terjadi komunikasi satu arah apabila komunikan atau peserta didik bersifat pasif dan tidak memberi respon atas apa yang disampaikan oleh komunikator atau guru.

Berdasarkan keterangan tersebut, maka peneliti menyimpulkan bahwa komunikasi yang dilakukan dalam bentuk diskusi atau komunikasi interaksi dalam proses belajar mengajar sangat efektif, baik antara peserta didik dengan peserta didik lainnya atau guru dengan peserta didik. Pentingnya proses diskusi dalam proses komunikasi ini disebabkan oleh: 
1. Materi yang didiskusikan meningkatkan intelektual peserta didik

2. Komunikasi dalam diskusi bersifat intra communication (komunikasi yang terjadi pada diri seseorang sebelum berkomunikasi dengan orang lain) dan intra communication (komunikasi yang dilakukan dengan orang lain.)

\section{Persepsi Peserta Didik mengenai Kemampuan Komunikasi Guru}

Komunikasi yang terjadi antar peserta didik akan menimbulkan berbagai persepsi mengenai kemampuan komunikasi guru. Persepsi peserta didik dapat timbul apabila peserta didik tersebut mengamati suatu obyek menggunakan perantara alat inderanya dengan penuh perhatian dan diteruskan ke syaraf terutama dalam memperhatikan kemampuan komunikasi guru dalam kegiatan pembelajaran.

Persepsi pesera didik mengenai kemampuan komunikasi guru merupakan suatu hal yang penting dalam peningkatan hasil belajar. Dalam proses belajar, tanpa adanya persepsi peserta didik mengenai kemampuan komunikasi guru maka pembelajaran tidak akan mencapai hasil yang maksimal. Dengan adanya persepsi peserta didik mengenai kemampuan komunikasi guru, peserta didik dapat mengetahui kemampuan komunikasi guru pada saat menjelaskan atau menyampaikan materi terutama pada mata pelajaran ekonomi.

\section{METODE}

Metode yang digunakan dalam penelitian ini adalah kuantitatif dengan pedekatan survey. Populasi dalam penelitian ini adalah peserta didik kelas XI Madrasah Aliyah (MA) An-Nizhamiyyah Cileungsi, Bogor dengan jumlah peserta didik sebanyak 32 orang, karena jumlah populasi termasuk kategori yang kurang dari 100, maka untuk sampel mengambil semua dari jumlah poplasi yang ada. Dalam hal ini teknik sampling yang digunakan adalah sampling jenuh.

\section{HASIL PENELITIAN DAN PEMBAHASAN}

Tabel 1. Rekapitulasi Hasil Perhitungan Data

\begin{tabular}{|c|c|c|c|c|c|}
\hline $\mathrm{N}$ & $\sum \mathrm{X}$ & $\sum \mathrm{Y}$ & $\sum \mathrm{X}^{2}$ & $\sum \mathrm{Y}^{2}$ & $\sum \mathrm{XY}$ \\
\hline $\mathbf{3 2}$ & $\mathbf{2 3 6 7}$ & $\mathbf{2 5 2 7}$ & $\mathbf{1 7 5 6 9 9}$ & $\mathbf{1 9 9 7 3 7}$ & $\mathbf{1 8 7 1 1 4}$ \\
\hline
\end{tabular}




\section{Analisis Regresi Sederhana}

Persamaan regresi adalah $\hat{y}=a+b x$

Setelah dilakukan perhitungan dari hasil rekapitulasi data yang ada, maka di dapat nilai sebagai berikut :

$a=55,518 \quad$ dan $\quad b=0,317$

Jadi persamaan regresi nya adalah $\hat{y}=55,518+0,317 x$

Artinya bahwa setiap perubahan nilai variabel $\mathrm{x}$ setiap satu satuan, maka akan mempengaruhi perubahan nilai variabel y sebesar 0,317 satuan, serta apabila nilai $\mathrm{x}$ mengalami kenaikan sebesar satu satuan, maka nilai y juga akan mengalami kenaikan, dan sebaliknya. Jadi dari hasil persamaan regresi tersebut adalah regresinya bernilai positif dan searah.

\section{Analisis Korelasi}

Untuk dapat memberikan besar atau kecilnya penafsiran terhadap koefisien korelasi yang ditentukan, maka dapat berpedoman pada ketentuan yang tertera pada tabel sebagai berikut :

Tabel 2. Interprestasi Koefisien Korelasi

\begin{tabular}{|c|c|}
\hline Interval Koefisien & Tingkat Hubungan \\
\hline $0,00-0,19$ & Sangat Rendah \\
$0,20-0,39$ & Rendah \\
$0,40-0,59$ & Sedang \\
$0,60-0,79$ & Kuat \\
$0,80-1,00$ & Sangat Kuat \\
\hline
\end{tabular}

Sumber : Sugiyono 2010:250

Untuk menganalis koefisen korelasi digunakan rumus korelasi product moment

$$
\begin{aligned}
& \mathrm{r}_{\mathrm{xy}}=\frac{n \sum X Y-\left(\sum X\right)\left(\sum Y\right)}{\sqrt{\left\{n \cdot \sum X^{2}-\left(\sum X\right)^{2}\right\}\left\{n \cdot\left(\sum Y^{2}\right)-\left(\sum Y\right)^{2}\right\}}} \\
& \mathrm{r}_{\mathrm{xy}}=0,581
\end{aligned}
$$

Dari perhitungan dan pedoman pada tabel 2, dapat diketahui bahwa terdapat hubungan nilai korelasi antara variabel Persepsi Peserta Didik mengenai Kemampuan Komunikasi Guru dengan variabel Hasil Belajar Ekonomi sebesar 0,581 yang berarti 
dapat disimpulkan bahwa hubungan antara variabel tersebut berada pada katagori sedang.

\section{Koefisen Determinasi}

Perhitungan koefisien determinasi digunakan untuk mengetahui seberapa besar kontribusi variabel $\mathrm{X}$ dengan variabel $\mathrm{Y}$ dengan rumus :

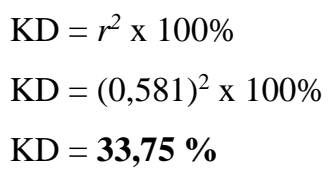

Berdasarkan hasil perhitungan tersebut, didapat koefisien determinasi sebesar $33,75 \%$. Hal ini menunjukkan bahwa kontribusi variabel Persepsi Peserta Didik mengenai Kemampuan Komunikasi Guru dengan variabel Hasil Belajar Ekonomi adalah sebesar $33,75 \%$ sedangkan sisanya $66,25 \%$ adalah merupakan kontribusi faktor lain yang tidak diteliti.

\section{Uji Hipotesis}

Pengujian ini dilakukan untuk mengetahui simpulan dari hasil penelitian, sehingg dapat mengambil keputusan apakah diterima atau ditolak. Rumus yang di gunakan sebagai berikut :

$$
\begin{aligned}
& t_{\text {hitung }}=\frac{r \sqrt{n-2}}{\sqrt{1-r^{2}}} \\
& t_{\text {hitung }}=\frac{0,581 \sqrt{32-2}}{\sqrt{1-0,581^{2}}} \\
& t_{\text {hitung }}=3,91
\end{aligned}
$$

Berdasarkan hasil thitung tersebut selanjutnya dibandingan dengan $t_{\text {tabel. }}$. Untuk kesalahan 5\% uji dua pihak dan $\mathrm{dk}=\mathrm{n}-2=30$, maka diperoleh $t_{\text {tabel }}=2,04$.

Setelah penulis menentukan hasil perhitungan $t_{\text {hitung }}$ dan $t_{\text {tabel }}$ dapat diketahui bahwa hasil thitung $3,91>t_{\text {tabel }} 2,04$, dengan ketentuan

a. Jika $t_{\text {hitung }}>t_{\text {tabel }}$ maka Ho ditolak sedangkan Ha diterima, (terdapat hubungan Variabel X dan variabel Y)

b. Jika $t_{\text {hitung }}<t_{\text {tabel }}$ maka Ho diterima sedangkan Ha ditolak, (tidak terdapat hubungan Variabel X dan variabel Y)

Dari hasil uji hipotesis diatas didapat hasil $t_{\text {hitung }}>t_{\text {tabel }}$ yaitu $t_{\text {hitung }} 3,91>t_{\text {tabel }}$ 2,04 berarti Ha diterima dan Ho ditolak. Maka dapat disimpulkan bahwa terdapat 
pengaruh persepsi peserta didik mengenai kemampuan komunikasi guru dengan hasil belajar ekonomi.

Berdasarkan hasil Perhitungan yang telah diuraikan, dan dilakukan analisis, maka dapat diinterpretasikan sebagai berikut :

1. Berdasarkan perhitungan regresi didapat data $\hat{y}=55,518+0,317 x$ hal ini menunjukkan bahwa nilai regresi tersebut bernilai positif dan searah.

2. Berdasarkan perhitungan korelasi didapat data $r_{\text {hitung }}$ sebesar 0,581 hal ini menunjukkan bahwa terdapat hubungan yang sedang antara variabel Persepsi Peserta Didik mengenai Kemampuan Komunikasi Guru dengan variabel Hasil Belajar Ekonomi.

3. Dari hasil koefisien determinasi didapat jumlah kontribusi persepsi peserta didik mengenai kemampuan komunikasi guru terhadap hasil belajar sebesar 33,75 \% dan sisanya dipengaruhi oleh faktor lain.

4. Berdasarkan hasil uji hipotesis didapat nilai $t_{\text {hitung }}$ sebesar 3,91 dan $t_{\text {tabel }}$ sebesar 2,04 yang berarti $t_{\text {hitung }}>t_{\text {tabel }}$ yang menyatakan bahwa terdapat pengaruh persepsi peserta didik mengenai kemampuan komunikasi guru terhadap hasil belajar ekonomi.

\section{SIMPULAN}

Berdasarkan hasil penelitian dan pembahasan yang diuraikan, serta dari hasil analisis dan perhitungan data yang telah dilakukan, dapat disimpulkan bahwa terdapat pengaruh persepsi peserta didik mengenai kemampuan komunikasi guru terhadap hasil belajar ekonomi peserta didik kelas XI di MA An-Nizhamiyyah Cileungsi, Bogor.

\section{UCAPAN TERIMA KASIH}

Pada kesempatan ini, kami mengucapkan puji syukur kepada Allah SWT, yang telah memberikan rahmat dan karunia-Nya. Tidak lupa juga kami mengucapkan terima kasih kepada semua pihak yang telah membantu, terutama kepada para peserta didik dan para guru mata pelajaran ekonomi, serta kepala sekolah MA. An-Nizhamiyyah Ciluengsi, Bogor. 
Research and Development Journal of Education

Vol. 3 No.1 Oktober 2016

ISSN 2406-9744

\section{DAFTAR PUSTAKA}

Cangara, Hafied. (2014). Perencanaan dan Strategi Komunikasi. Jakarta: Rajawali Press.

Hidayat, Syarif. (2013). Teori dan Prinsip Pendidikan. Tangerang: Pustaka Mandiri.

Kennedy dan Soemanagara. (2009). Marketing Communication. Jakarta: Prestasi Pustaka.

Rakhmat, Jalaludin. (2007). Psikologi Komunikasi. Bandung: Remaja Rosdakarya.

Slameto. (2010). Belajar dan Faktor-faktor yang Mempengaruhinya. Jakarta: Rineka Cipta.

Sudjana, Nana. (2009). Penelitian dan Penilaian Pendidikan. Bandung: Sinar Baru Algesindo.

Sugiyono. (2010). Metode Penelitian Bisnis. Bandung : Alfabeta.

Surakhmad, Winarto. (2012). Strategi Belajar. Jakarta: Bumi Aksara.

Syah, Muhibbin. (2010). Komunikasi Media Massa. Jakarta: Bumi Aksara.

\section{Peraturan Perundangan}

Undang Undang Nomor 20 Tahun 2003 tentang Sistem Pendidikan Nasional.

\section{Jurnal}

Amalia, I. (2012). Hubungan Persepsi Tentang Kompetensi Guru Dan Penyesuaian Diri Siswa Dengan Hasil Belajar Bahasa Inggris Kelas IV SD Se-Kecamatan Pejagon, 1 (3) hlm. 